\title{
THE RESULTS OF IMPLEMENTATION OF EUROPEAN REQUIREMENTS IN MANAGEMENT OF TRANSFER PRICING AUDIT (EXPERIENCE OF UKRAINE)
}

\author{
Valeriia Fesenko \\ University of Customs and Finance, Ukraine \\ E-mail: FesenkoValery@i.ua \\ Olena Vakulchyk \\ University of Customs and Finance, Ukraine \\ E-mail: elvak2016@gmail.com \\ Olexandr Guba \\ University of Customs and Finance, Ukraine \\ E-mail: gubaalex1025@gmail.com
}

\begin{abstract}
Serhii Ostapchuk
National Scientific Centre "Institute of Agrarian Economics", Ukraine

E-mail: ostapchuk@faaf.org.ua

Iryna Babich

Lutsk National Technical University, Ukraine

E-mail:iibabich@ukr.net

Submission: $8 / 12 / 2020$

Revision: 8/26/2020

Accept: 9/8/2020
\end{abstract}

\section{ABSTRACT}

Since 2017 four of fifteen steps of the BEPS plan (base erosion and profit shifting) have been introduced in Ukraine to resist various areas of aggressive tax planning. The implementation of the BEPS plan is primarily made through frame working a transfer pricing control system in Ukraine, which aims to reduce illegal tax sheltering through foreign economic transactions with interdependent or interested parties as well as through transactions with contractors that are registered or make business in low-tax jurisdictions. The purpose of this study is to evaluate the results of implementation of European requirements in the system of audit of foreign economic activity in Ukraine. The study is based on data from the State Statistics Committee of Ukraine, the State Fiscal Service of Ukraine for 2015-2019. The article identifies the amounts of Ukrainian exports (imports) to (from) low-tax jurisdictions, analyzes the controlled exports and imports by geographical segment. 
DOI: 10.14807/ijmp.v11i9.1412

The study presents evidence of the use of transfer pricing mechanisms by Ukrainian companies to optimize income taxation, which is contrary to the interests of the state. Therefore, a special need consists in improvement of the state control over operations of the foreign economic activity. The changes and current trends in foreign economic operations during the implementation of transfer pricing controls since 2013 in accordance with the BEPS plan were examined. This study proves that immediately after expanding the list of low tax jurisdictions, there has been a significant fall in the volume of controlled exports and imports, which we regard as a loss of cost-effectiveness of trade operations through low tax jurisdictions due to increased controls and enlarged list of territories, transactions through which are under strict control.

Keywords: Transfer pricing audit; Foreign economic activity; Finance of international companies; Offshore; Low-tax jurisdictions; BEPS-plan

\section{INTRODUCTION}

The European integration processes that have been running in Ukraine over the last years frame the task of the European Union (EU) standards implementation into management of transfer prices' auditing and control of foreign economic operations of international companies. The gradual implementation of the Organization for Economic Co-operation and Development's (OECD) roadmap to counteract tax bases erosion and income tax evasion is carried out by adapting the requirements of the Tax Code of Ukraine (TCU) to European standards in the field of transfer pricing control and special control of operations performed with contractors from offshore territories.

The implementation of the OECD roadmap to counter tax base erosion and income tax evasion (BEPS - Base Erosion and Profit Shifting) is supposed to limit uncontrolled exports and imports, reduce the number of tax-evaded incomes and positively affect tax revenues from foreign economic activities.

The implementation of the BEPS plan has begun in Ukraine since 2013 and continues today through more expanded requirements introduced into taxation and audit of foreign economic activities in accordance with the OECD standards. Since 2017 four of fifteen steps of the BEPS plan have been introduced in Ukraine to resist various areas of aggressive tax planning: combating tax abuse related to the application of special tax regimes; elimination of abuses while implementing tax conventions; disclosure of the use of aggressive tax planning 
DOI: 10.14807/ijmp.v11i9.1412

schemes; improving the effectiveness of dispute settlement mechanisms related to the application of double tax avoidance treaties between countries.

The implementation of the BEPS plan is primarily made through frame working a transfer pricing control system in Ukraine, which aims to reduce illegal tax sheltering through foreign economic transactions with interdependent or interested parties as well as through transactions with contractors that are registered or make business in low-tax jurisdictions. The enforcement of a transfer pricing control system will lead to an increase in tax revenues to the country's budget in accordance with the tax legislation of Ukraine.

\section{LITERATURE REVIEW}

Many foreign publications deal with the issues of avoiding taxation through offshore territories by means of transfer pricing mechanisms. The question of transfer pricing control and management in the context of tax optimization was investigated by DEVEREUX and MAFFINI (2007), LOHSE and RIEDEL (2013), MARQUES and PINHO (2015), RUF AND WEICHENRIEDER (2015), HUDA, NUGRAHENI and KAMARUDIN (2017), MELNYCHENKO, PUGACHEVSKA and KASIANOK (2017) PRETTL (2018), BEEBEEJAUN (2019), CLIFFORD (2019), HIRA, MURATA and MONSON (2019).

These studies also include investigation various aspects of the implementation of European standards into the system of audit of transfer prices and operations through offshore zones. In the study of HUDA, NUGRAHENI and KAMARUDIN (2017) the issue of transfer pricing control in the Indonesian tax system is researched, which concludes that transfer pricing schemes are used by multinational companies to avoid tax payments by transferring their tax liabilities to other countries with lower tax rates.

A similar conclusion is reached by MELNYCHENKO, PUGACHEVSKA and KASIANOK (2017), who argue that the transfer price generated by a multinational company between two units is an economic and legal tool used to optimize the tax burden. LOHSe and RIEDEL (2013) published results of a study assessing the impact of transfer pricing rules on the behavior of multinational companies in intra-group price distortions, where the authors argue that the introduction of certain transfer pricing rules increases the profits that are reflected in the profitability of businesses in high tax jurisdictions, and reduce them in low tax jurisdictions.

MARQUES and PINHO (2015) argue that increasing rigidity in transfer pricing regulation reduces the sensitivity of reported earnings to differences in tax rates. But there are 
DOI: 10.14807/ijmp.v11i9.1412

also critics of tightening transfer pricing controls for AVI-YONAH, CLAUSING and DURST (2009), who believe that such rules only complicate the management process and increase the cost of preparing a transfer pricing report.

Some studies have revealed the experience of implementing the BEPS plan and the relevant requirements for auditing the foreign economic activities of multinationals. In particular, WEST's (2017) scientific work focuses on the introduction of the BEPS and CRS (Common Reporting Standards) plan in South Africa and their influence on the domestic legislation. The issue of offshore zones and transfer pricing are investigated not only in the field of tax control over these processes, but also from the side of evaluating the effectiveness of offshore transactions performed by the entities conducting such operations. Thus, LARSEN (2015) studies errors while estimating the cost of offshore operations and the impact of these errors on the performance of individual units.

Researching the OECD's gradual implementation of the BEPS plan, ECCLESTON and SMITH (2016) make an interesting conclusion in their work by arguing that BEPS will not succeed in its attempts to restrict the growing aggressive tax planning practices of multinational corporations. These researches state that while assessing issues of control related to international taxation, it is necessary to outline the conceptual differences (and political implications) between facilitation of international tax transparency, on the one hand, and regulation of international tax competition that makes tax evasion possible, on the other.

But most authors are CLIFFORD (2019), RUF and WEICHENRIEDER (2015), PRETTL (2018), DEVEREUX and MAFFINI (2007) agree that the implementation of transfer pricing controls has a positive effect on tax revenues and the behavior of multinational companies in the field of tax optimization: forcing TNCs to profit from the high tax jurisdictions in which they were actually established; changing the structure of enterprise groups towards reducing the number of subsidiaries in low-tax jurisdictions; there is an increase in tax revenues in countries that enforce transfer pricing controls.

Studies of the process of the European standards implementation into the system of audit and taxation of foreign economic activities of Ukraine are made in different directions. In particular, scientists IVASHOVA and IVASHOV (2014), upon having made an analysis of the EU experience in the sphere of state control and directions of its implementation in Ukraine, identified a number of material, technical, organizational, information and personnel support issues and specified the directions of improving the work of government control and audit 
DOI: 10.14807/ijmp.v11i9.1412

services, which, in our opinion, can be used for improving the state control of foreign economic activities of enterprises as well.

The introduction of European standards into the system of audit of foreign economic activities of Ukraine is closely connected with the development of Customs post-audit. So, the works of PETRYK and MARYNICH (2015) look into the issue of Customs post-audit creation in Ukraine, in which the authors conclude that the introduction of Customs post-audit control is an essential condition for further integration of the Ukrainian economy into the European community and consider it necessary to involve audit companies in Customs post-audit control. This will allow reaching the level of the best world practices concerning the maximum reduction of time spent on Customs clearance and will ensure constant compliance with Customs legislation by foreign trade participants.

VAKULCHYK, FESENKO and KNYSHEK (2017) study the features of the audit of compliance of the enterprises carrying out foreign economic activity with the European standards of the Authorized Economic Operator, which makes it possible to offer a model of assessment of an enterprise's compliance with these requirements and which is already a methodological basis for enterprises' self-assessment of their status in accordance with European standards.

Separately, some scientific works have revealed the issues of creation of transfer pricing control in Ukraine since 2013. In particular, the works of ALEKSEEVA (2014), VAKULCHYK (2016), PETRYK (2016), FESENKO (2018) describe the experience of Ukraine in the field of transfer pricing control, the main tendencies and prospects of its development, which is also significant for the implementation of European standards into the control and audit of foreign economic activity of enterprises.

Despite the considerable achievements in making an analysis of the process of the European standards implementation into the legislation of different countries with a transition economy as well as the BEPS plan introduction in Ukraine, modern publications almost do not study the economic effect of the European standards implementation into auditing and taxation of foreign economic activities of Ukraine. Therefore, we consider it feasible to investigate the evolution of the main economic indicators, which may identify positive changes and reduction of abuse and fraud within foreign trade operations in Ukraine.

Based on the abovementioned, the purpose of the research is to evaluate the impact of the adaptation of European requirements in sphere of management of transfer price's audit on 
DOI: 10.14807/ijmp.v11i9.1412

the volume and structure of foreign economic activities of Ukraine and to identify current trends in the management of foreign economic operations of groups of international companies.

\section{METHODOLOGY}

The methodological basis of the study are the fundamental provisions of modern economic science, a set of general and special methods of cognition, in particular: the method of induction and deduction (to determine the criteria for attributing countries to low-tax jurisdictions), the method of systematic approach (to summarize and systematize the results of analysis and analysis of the results of analysis), a method of comparing and structuring analysis of Ukraine's statistics (in determining the top 10 countries of export and import to (from) low tax jurisdictions).

The study is based on data from the State Statistics Committee of Ukraine, the State Fiscal Service of Ukraine. The study was conducted on the basis of data for 2015-2019.

\section{RESULTS AND DISCUSSIONS}

One of the directions of control and regulation under the BEPS plan is an expanded list of jurisdictions, trade operations with which residents are subject to tighter control by the State Fiscal Service of Ukraine. Within the framework of implementation of the rules of transfer pricing control into the legislation of Ukraine, business transactions carried out with nonresidents registered in the states (territories) included in the relevant list of the Cabinet of Ministers of Ukraine are subject to careful audit. Together with the entry into force of the relevant laws and regulations of the Tax Code of Ukraine, special rules to regulate transactions with contractors registered and paying taxes in countries with low income tax rates are introduced.

Thus, Ukraine has adopted a number of normative documents to specify the list of states and territories (offshore zones), transactions with which are subject to state tax control.

These documents list the states and territories, transactions with which residents are considered controlled.

An important task is to determine whether tightening control actually results in the consequent reduction of exports and imports through low-tax jurisdictions. To assess the overall dynamics of foreign economic activity in Ukraine, it is advisable to demonstrate the volume of foreign trade in Ukraine in recent years (figure 1). 


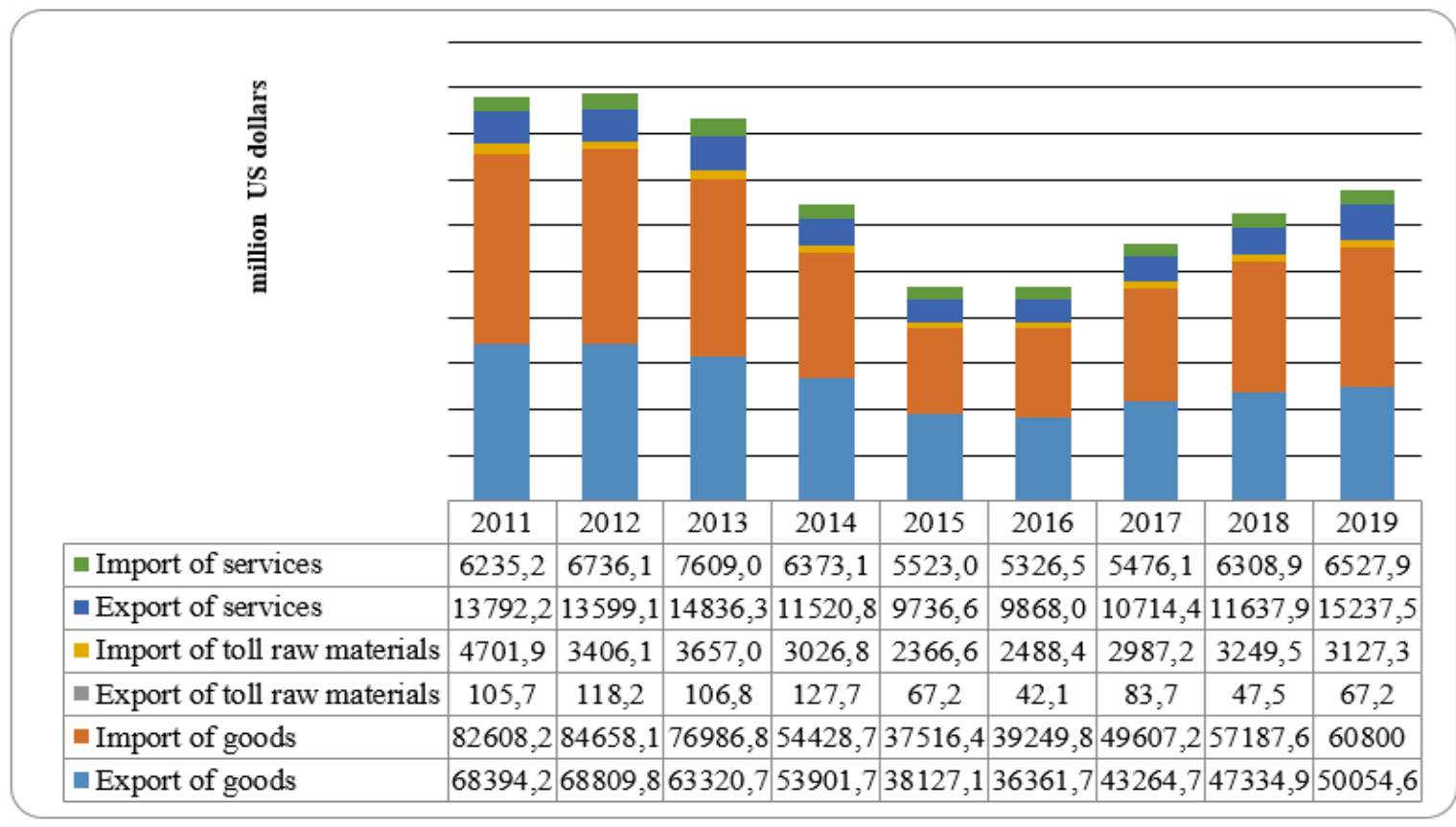

Figure 1: Dynamics of foreign trade in goods, services and toll raw materials in Ukraine (million USD)

Source: calculated by authors on the data of State Statistics Service of Ukraine

The total amount of foreign trade in 2011 and 2012 was almost at the same level (175837.4 and 177327.4 million US dollars), but since 2013 the volume of foreign trade is gradually declining and reaches a minimum in 2016 - 93336.5 million dollars USA.

The failure in foreign trade in 2013-2016 is explained by the known reasons of militarypolitical and economic nature, which became the main negative factors influencing the level of foreign economic activity of Ukraine. Since 2017, there has been a gradual increase in Ukraine's total foreign trade, but even in 2019 Ukraine did not reach the level of 2011-2012.

Figure 2 shows the volume of Ukrainian exports to low-tax jurisdictions during 2018. The largest volume of exports among the countries recognized by the Cabinet of Ministers of Ukraine as low-tax jurisdictions in 2018 were reported to be brought into Bulgaria, Iran, Spain, Singapore, Lebanon, Moldova, Morocco, Serbia, Uzbekistan, the UAE.

Along with the expansion of the list of states and territories (offshore zones), trade operations with which are subject to the state tax control, the volume of exports to these territories changes as well. 
DOI: 10.14807/ijmp.v11i9.1412

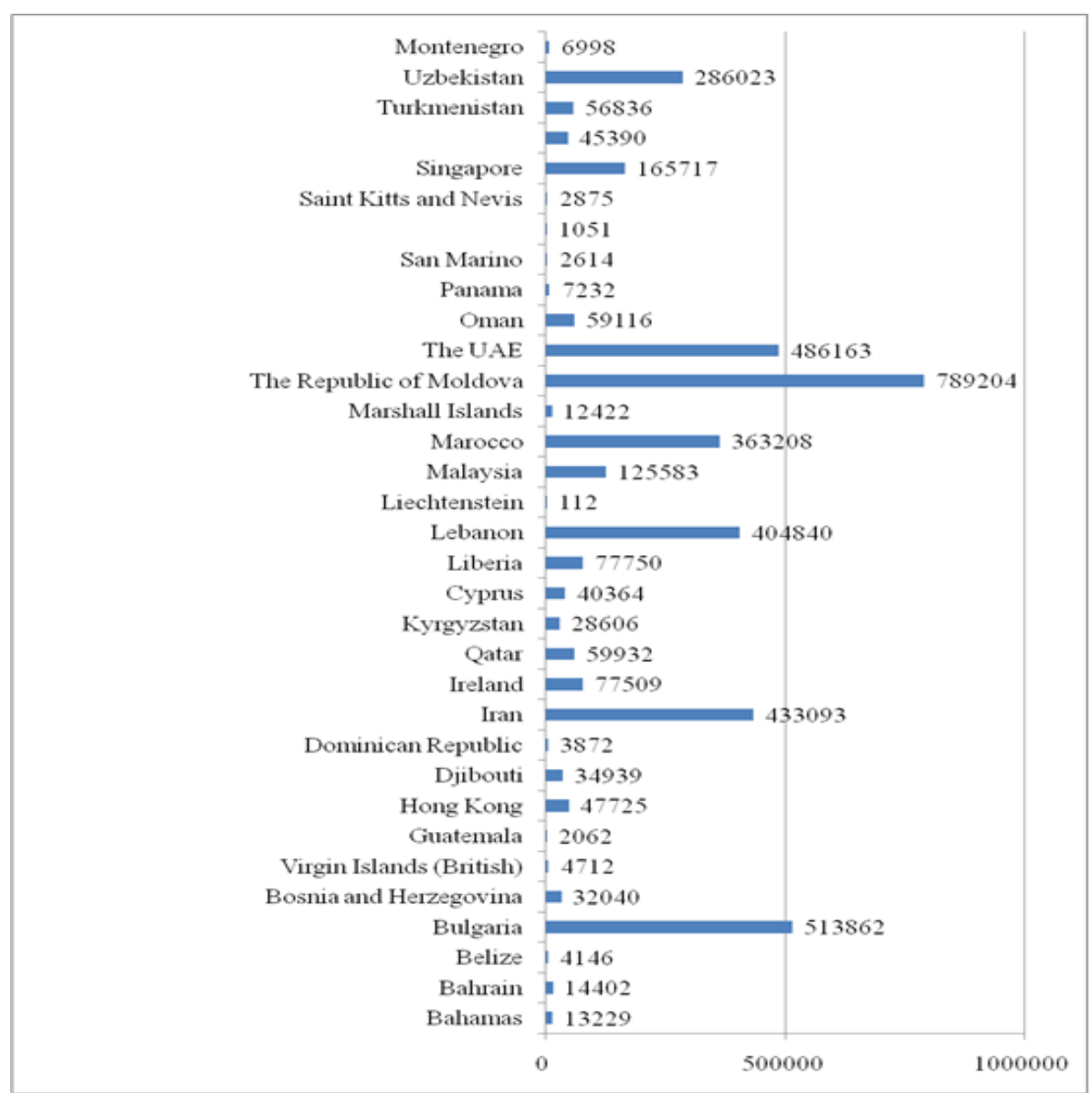

Figure 2: Exports from Ukraine to low-tax jurisdictions (according to the Cabinet of Ministers of Ukraine list) during 2018, thousand US dollars Source: calculated by authors on the data of State Statistics Service of Ukraine

Table 1 lists low-tax jurisdictions with the largest export volumes during 2016-2019.

Table 1: TOP-10 low-tax jurisdictions by volume of exports from Ukraine during 2016-2019

\begin{tabular}{|c|c|c|c|c|c|c|c|}
\hline \multicolumn{2}{|c|}{2016} & \multicolumn{2}{|c|}{2017} & \multicolumn{2}{|c|}{2018} & \multicolumn{2}{|c|}{2019} \\
\hline Country & $\begin{array}{c}\text { Amount, } \\
\text { thousand } \\
\text { US } \\
\text { dollars }\end{array}$ & Country & $\begin{array}{c}\text { Amount, } \\
\text { thousand } \\
\text { US } \\
\text { dollars }\end{array}$ & Country & $\begin{array}{l}\text { Amount, } \\
\text { thousand } \\
\text { US dollars }\end{array}$ & Country & $\begin{array}{c}\text { Amount, } \\
\text { thousand } \\
\text { US } \\
\text { dollars }\end{array}$ \\
\hline $\begin{array}{l}\text { The Republic } \\
\text { of Moldova }\end{array}$ & 481145.4 & $\begin{array}{l}\text { The Republic } \\
\text { of Moldova }\end{array}$ & 707583.5 & $\begin{array}{l}\text { The } \\
\text { Republic of } \\
\text { Moldova }\end{array}$ & 789204.3 & $\begin{array}{l}\text { The } \\
\text { Republic of } \\
\text { Moldova }\end{array}$ & 726568.7 \\
\hline Bulgaria & 418193.3 & Bulgaria & 429904.9 & Bulgaria & 513862.3 & $\begin{array}{l}\text { The United } \\
\text { Arabic } \\
\text { Emirates }\end{array}$ & 525937.3 \\
\hline Serbia & 156132.5 & Uzbekistan & 167113.3 & $\begin{array}{l}\text { The United } \\
\text { Arabic } \\
\text { Emirates }\end{array}$ & 486162.9 & Bulgaria & 482168.2 \\
\hline Uzbekistan & 142392.7 & Serbia & 156132.5 & Iran & 433092.6 & Lebanon & 372125.0 \\
\hline Turkmenistan & 108981.9 & Malaysia & 130670.2 & Lebanon & 404839.5 & Morocco & 294070.2 \\
\hline Cyprus & 53481.4 & Cyprus & 79637.6 & Morocco & 363207.9 & Uzbekistan & 215821.1 \\
\hline Oman & 51870.5 & Turkmenistan & 62142.3 & Uzbekistan & 286023.2 & Iran & 214727.4 \\
\hline Hong Kong & 49013.4 & Ireland & 55298.4 & Singapore & 165717.1 & Singapore & 188523.8 \\
\hline Ireland & 45483.9 & Hong Kong & 54074.8 & Serbia & 156132.5 & Malaysia & 181606.2 \\
\hline Kyrgyzstan & 40430.8 & Oman & 51870.5 & Malaysia & 125583.4 & Ireland & 153235.2 \\
\hline
\end{tabular}

Source: calculated by authors on the data of State Statistics Service of Ukraine 
DOI: 10.14807/ijmp.v11i9.1412

Figure 3 shows the volume of imported goods to Ukraine in 2018 from the countries included in the list of low-tax jurisdictions in accordance with the Cabinet of Ministers of Ukraine Decree No. 1045 from December 27, 2017.

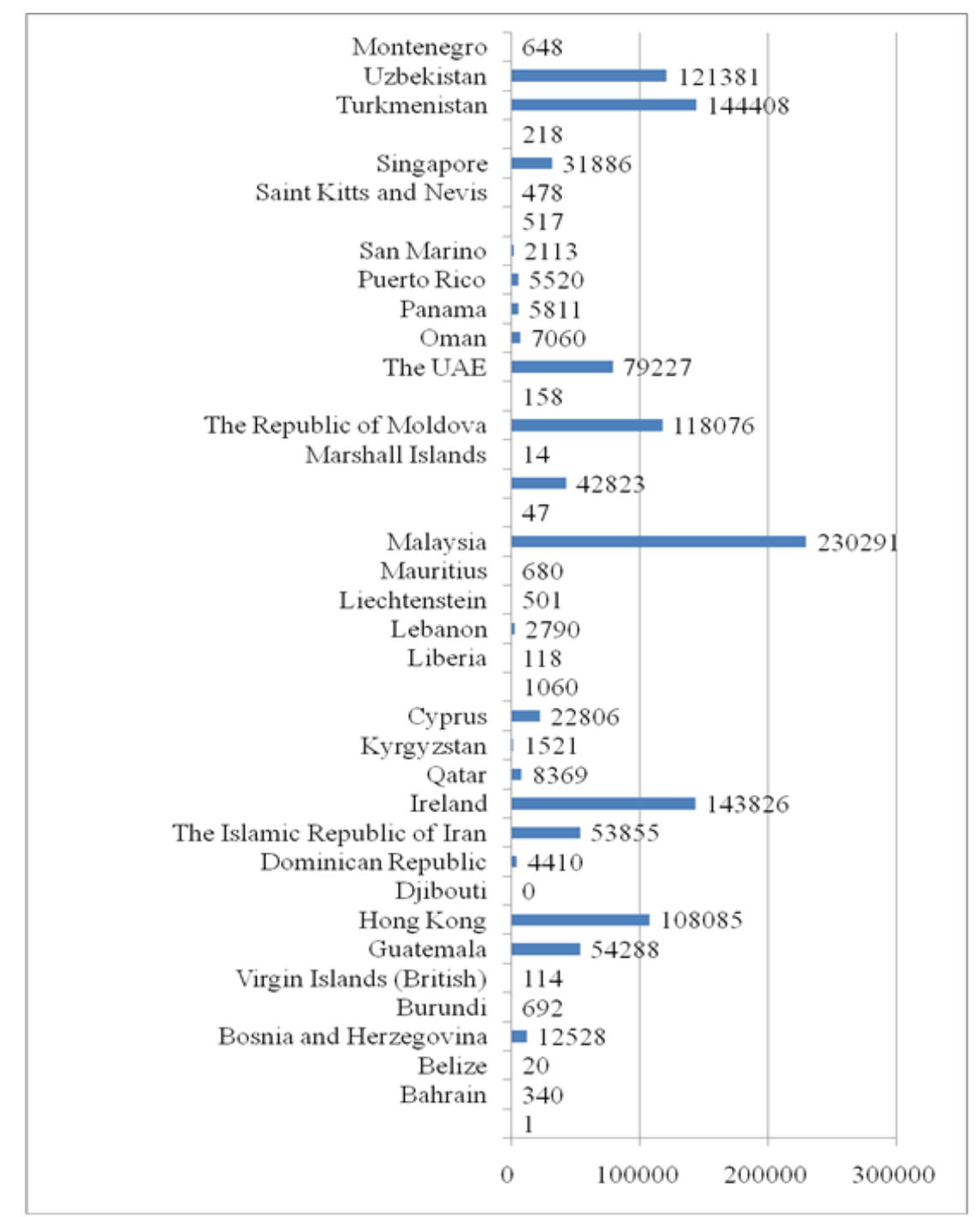

Figure 3: Import volumes to Ukraine from low-tax jurisdictions during 2018, thousand US dollars

Source: calculated by authors on the data of State Statistics Service of Ukraine

The largest volumes of imports among the countries included by the Cabinet of Ministers of Ukraine in the list of low-tax jurisdictions in 2018 were reported from Spain, Malaysia, Turkmenistan, Ireland, Uzbekistan, Moldova, Hong Kong, Guatemala, Iran, the UAE.

Table 2 shows the low-tax jurisdictions, the largest volumes of imports from which were identified during 2016-2019.

Table 2 shows that among the countries included in the list of low-tax jurisdictions in the respective years leading importers by volume of goods brought into Ukraine are Bulgaria 
DOI: 10.14807/ijmp.v11i9.1412

(the first place in 2016 and 2017), Malaysia (the second place in 2017 and the first place in 2018), Ireland, Turkmenistan, and Uzbekistan.

Table 2: TOP-10 low-tax jurisdictions by volume of imports to Ukraine during 20162019

\begin{tabular}{|c|c|c|c|c|c|c|c|}
\hline \multicolumn{2}{|c|}{2016} & \multicolumn{2}{|c|}{2017} & \multicolumn{2}{|c|}{2018} & \multicolumn{2}{|c|}{2019} \\
\hline Country & $\begin{array}{c}\text { Amount, } \\
\text { thousan } \\
\text { d US } \\
\text { dollars }\end{array}$ & Country & $\begin{array}{c}\text { Amount, } \\
\text { thousan } \\
\text { d US } \\
\text { dollars }\end{array}$ & Country & $\begin{array}{c}\text { Amount, } \\
\text { thousan } \\
\text { d US } \\
\text { dollars }\end{array}$ & Country & $\begin{array}{c}\text { Amount, } \\
\text { thousan } \\
\text { d US } \\
\text { dollars }\end{array}$ \\
\hline Bulgaria & 172873.8 & Bulgaria & 189933.3 & Malaysia & 230291.1 & Bulgaria & 459341.9 \\
\hline Serbia & 106506.9 & Malaysia & 189904.4 & $\begin{array}{c}\text { Turkmenista } \\
n\end{array}$ & 144407.9 & Malaysia & 230331.3 \\
\hline Ireland & 84712.5 & Uzbekistan & 122721.1 & Ireland & 143826.1 & Ireland & 169564.7 \\
\hline Uzbekistan & 71060.2 & Ireland & 113890.3 & Uzbekistan & 121381.1 & Uzbekistan & 112740.8 \\
\hline $\begin{array}{c}\text { The } \\
\text { Republic of } \\
\text { Moldova }\end{array}$ & 47623.2 & $\begin{array}{c}\text { The } \\
\text { Republic of } \\
\text { Moldova }\end{array}$ & 106719.5 & $\begin{array}{c}\text { The } \\
\text { Republic of } \\
\text { Moldova }\end{array}$ & 118076.0 & Morocco & 100549.7 \\
\hline $\begin{array}{c}\text { Turkmenista } \\
\mathrm{n}\end{array}$ & 34336.1 & Guinea & 97788.9 & Hong Kong & 108085.0 & $\begin{array}{c}\text { The } \\
\text { Republic of } \\
\text { Moldova }\end{array}$ & 91250.6 \\
\hline Qatar & 26268.8 & $\begin{array}{c}\text { Turkmenista } \\
\mathrm{n}\end{array}$ & 89345.8 & $\begin{array}{c}\text { The United } \\
\text { Arabic } \\
\text { Emirates }\end{array}$ & 79227.0 & Hong Kong & 87692.7 \\
\hline Cyprus & 22081.6 & Hong Kong & 29120.1 & Singapore & 65016.0 & $\begin{array}{c}\text { Turkmenista } \\
\mathrm{n}\end{array}$ & 82964.6 \\
\hline Hong Kong & 17629.9 & Cyprus & 20527.1 & Guatemala & 54288.4 & $\begin{array}{c}\text { The United } \\
\text { Arabic } \\
\text { Emirates }\end{array}$ & 80544.8 \\
\hline $\begin{array}{l}\text { Bosnia and } \\
\text { Herzegovina }\end{array}$ & 10776.0 & $\begin{array}{l}\text { Bosnia and } \\
\text { Herzegovina }\end{array}$ & 12491.3 & $\begin{array}{l}\text { The Islamic } \\
\text { Republic of } \\
\text { Iran }\end{array}$ & 53854.8 & $\begin{array}{l}\text { The Islamic } \\
\text { Republic of } \\
\text { Iran }\end{array}$ & 48956.2 \\
\hline
\end{tabular}

At the stage of introduction of transfer pricing control mechanisms, the list of territories considered as offshore zones was added and the Decree of the Cabinet of Ministers of Ukraine from December 25, 2013 No. 1042-p significantly increased the number of states, transactions with which residents are subject to state control (Table 3).

As it can be seen from Table 3, the number of states and territories subject to state control changes quite often due to the adoption of new regulations. Major changes for international business happened in 2014, when the number of such areas increased rapidly from 36 up to 73 countries.

Studying the territorial aspects of foreign economic activity of business entities in Ukraine over the years, it should be highlighted that this expansion has significantly raised the amount of controlled transactions. In particular, in 2014 the number of states from the list of 
DOI: 10.14807/ijmp.v11i9.1412

offshore zones used for foreign economic activity of entities grew from 14 up to 35 compared to 2013.

Table 3: The ratio of the number of states (territories), transactions with which are controlled by a state in accordance with the legislation of Ukraine

\begin{tabular}{|c|c|c|c|c|c|c|}
\hline \multirow{2}{*}{ Indicators } & \multicolumn{6}{|c|}{$\begin{array}{l}\text { The reporting period under study, for which business entities are required to } \\
\text { provide information on controlled transactions (years) }\end{array}$} \\
\hline & 2013 & 2014 & 2015 & 2016 & 2017 & 2018 \\
\hline $\begin{array}{l}\text { The number of offshore } \\
\text { states (territories) from the } \\
\text { list involved in export- } \\
\text { import of Ukraine }\end{array}$ & 14 & 35 & 38 & 32 & 29 & 39 \\
\hline $\begin{array}{l}\text { The statutory document } \\
\text { defining the list of offshore } \\
\text { territories }\end{array}$ & $\begin{array}{l}\text { The Decree of } \\
\text { the Cabinet of } \\
\text { Ministers of } \\
\text { Ukraine No. } \\
\text { 143-r from } \\
\text { February 23, } \\
2011\end{array}$ & \multicolumn{2}{|c|}{$\begin{array}{l}\text { The Decree of the } \\
\text { Cabinet of Ministers } \\
\text { of Ukraine No. 1042-p } \\
\text { from December 25, } \\
2013\end{array}$} & \multicolumn{2}{|c|}{$\begin{array}{l}\text { The Decree of } \\
\text { the Cabinet of } \\
\text { Ministers of } \\
\text { Ukraine No. } \\
\text { 977-p from } \\
\text { September 16, } \\
2015\end{array}$} & $\begin{array}{l}\text { The Resolution of } \\
\text { the Cabinet of } \\
\text { Ministers of } \\
\text { Ukraine No. } 1045 \\
\text { from December } \\
\text { 27, } 2017\end{array}$ \\
\hline $\begin{array}{l}\text { The number of states } \\
\text { (territories) included in the } \\
\text { list }\end{array}$ & 36 & 73 & 73 & 65 & 65 & 85 \\
\hline $\begin{array}{l}\text { Percentage of enterprises } \\
\text { involved in foreign } \\
\text { economic activities of } \\
\text { Ukraine according to the } \\
\text { Cabinet of Ministers of } \\
\text { Ukraine list, \% }\end{array}$ & $39 \%$ & $48 \%$ & $52 \%$ & $49 \%$ & $\begin{array}{l}45 \\
\%\end{array}$ & $45.9 \%$ \\
\hline
\end{tabular}

Source: calculated by the authors

During 2016-2018 from 29 up to 39 offshore zones were used for foreign economic operations of Ukrainian business entities, which is about half of the offshore zones controlled by the state (Table 4 ).

Table 4: The indicators of export-import of goods of Ukraine to (from) countries (territories), transactions with which are controlled by the government

\begin{tabular}{|c|c|c|c|c|}
\hline \multirow{2}{*}{ The indicators of export/import of goods } & \multicolumn{3}{|c|}{ The period under study (years) } \\
\cline { 2 - 4 } & 2015 & 2016 & 2017 & 2018 \\
\hline $\begin{array}{c}\text { Volumes of exported goods of Ukraine, thousand } \\
\text { US dollars }\end{array}$ & $38,127,150$ & $36,361,711$ & $43,264,736$ & $47,334,987$ \\
\hline $\begin{array}{c}\text { Volumes of exported goods to the countries } \\
\text { (territories) from the Cabinet of Ministers of } \\
\text { Ukraine list, thousand US dollars }\end{array}$ & $3,130,862$ & $1,650,089$ & $2,044,867$ & $5,586,273$ \\
\hline $\begin{array}{c}\text { The share of exports to offshore zones in the total } \\
\text { amount of exports of Ukraine, } \%\end{array}$ & $\mathbf{8 . 2 1}$ & $\mathbf{4 . 5 4}$ & $\mathbf{4 . 7 2}$ & $\mathbf{1 1 . 8}$ \\
\hline $\begin{array}{c}\text { Volumes of imported goods of Ukraine, thousand } \\
\text { US dollars }\end{array}$ & $37,516,443$ & $39,249,797$ & $49,607,174$ & $57,187,578$ \\
\hline $\begin{array}{c}\text { Volumes of imported goods from the countries } \\
\text { (territories) included in the Cabinet of Ministers } \\
\text { of Ukraine list, thousand US dollars }\end{array}$ & $1,422,573$ & 610,111 & $1,000,680$ & $1,843,434$ \\
\hline $\begin{array}{c}\text { The share of imports from offshore zones in the } \\
\text { total amount of imports of Ukraine, } \%\end{array}$ & $\mathbf{3 . 7 9}$ & $\mathbf{1 . 5 5}$ & $\mathbf{2 . 0 2}$ & $\mathbf{3 . 2 2}$ \\
\hline
\end{tabular}

Source: calculated by authors on the data of State Statistics Service of Ukraine 
DOI: 10.14807/ijmp.v11i9.1412

It is interesting that along with the increase in the number of controlled offshore zones in 2014, the share of export of goods to the countries from the list of offshore zones in the total amount of export of Ukraine grew (from $0.95 \%$ up to $8.57 \%$ ). As mentioned above, the number of territories considered as being controlled by the government in 2014 increased from 14 up to 35 compared to 2013 (Table 3).

At the same time, in 2014 there was seen the growth in the share of exports and imports to (from) territories, the trade operations with which are considered state controlled, in the total volume of exports (imports) of Ukraine (Table 4).

It is interesting to point out that in 2018 Cyprus, which is a well-known offshore area, did not rank in top-10 low-tax jurisdictions. However, export to Cyprus has not stopped for many years. It means that even if tax control becomes tighter, the interest of entities involved in foreign trade in the opportunities offered by low-tax jurisdictions (tax allowances, simplified accounting, taxation and reporting, etc.) does not decrease.

The list of offshore areas shifts from time to time and in different countries these areas may be located in various territories and states. In general, an offshore zone is defined as a free economic zone with particularly favorable currency-financial and fiscal regimes, a simplified system of taxpayers' registration, a high level of confidentiality and loyalty of state control and regulation. Typically, offshore areas have low or zero tax rates as well as simplified licensing conditions.

Some countries draw up an appropriate lists of offshore zones, which are more thoroughly controlled. They include black, grey and white lists of offshore zones. The white list consists of those countries that, though having simplified taxation and registration conditions, sign relevant economic treaties on tax information sharing. The grey list of offshore zones includes those countries that sign a slight number of economic agreements on tax information sharing or are just about to do so. The black list is a list of territories and states with significant tax simplifications, suspected of money laundering and refusing to provide additional tax information.

Each country has its own black list of offshores, which is updated annually. Most countries include the Bahamas, Barbados, Cyprus, Monaco, Jersey, the Isle of Man and others in it.

Branches in such countries or transactions with their residents lead to additional tax control and in some countries even additional taxation. 
DOI: 10.14807/ijmp.v11i9.1412

Foreign economic transactions with residents from such territories create a conflict of interests between a business and a state, which means opposite interests (entities prefer to choose territories with tax allowances and simplified regulation to make their business, while a state fights to receive appropriate income tax revenues).

The fact that the list of such territories was supplemented according to the Cabinet of Ministers of Ukraine Decree in 2013 confirms that enterprises of Ukraine actually performed a large volume of foreign economic transactions with contractors from those territories where income tax rates were significantly different (the difference exceeded 5\%). This means that until 2014 Ukrainian enterprises virtually sought for income tax evasion through transactions in low-tax jurisdictions. The abovementioned trend in 2014 points to the obvious consequence of relevant regulations adoption expressed in the identification of significant volumes of exports and imports of local enterprises to low-tax jurisdictions that earlier were controlled by the government.

In 2015 and 2016 the volume of exported goods to controlled offshore areas halved and their share reached $4.54 \%$ in the total amount of exports. The volume of imports from controlled offshore areas is also decreasing and its share in the total amount of Ukrainian import reaches $1.55 \%$. Such a trend testifies the reduction in foreign economic transactions previously carried out by local enterprises in low tax jurisdictions. It shows that due to strengthened state tax control such transactions have lost their cost-effectiveness. In 2017 decreasing of controlled exports and imports to offshore territories continued, but in 2018 a notable rise was reported the share of exports to offshore zones in the total amount of exports of Ukraine increased up to $11.8 \%$, while the share of imports from offshore zones in the total amount of imports rose up to $3.22 \%$.

It is difficult to assess the effect of controlled exports and imports growth on tax revenues increase. However, within the execution of transfer pricing control some results of the State Fiscal Service of Ukraine audits of foreign economic activities of enterprises involving transfer pricing were reported, which testify to positive tendencies. The first results of audits by the State Fiscal Service of Ukraine of the reports on controlled transactions are presented and it is determined that in the period from 2013-2016, 206 violations were established during the audits of the reports on controlled transactions, after which the income tax amounted to UAH 297.8 million. As a result of the audit of the documentation on transfer pricing of Ukrainian enterprises in 2018, a profit tax of UAH 232 million was reduced, losses 
were reduced by UAH 1.6 billion, and the tax base was voluntarily increased by UAH 1.7 billion.

Results of audits of expediency and completeness of reports on controlled operations for the reporting periods in 2013-2016 are in the table 5.

Table 5: Results of audits made by the State Fiscal Service of Ukraine of expediency and completeness of reports on controlled operations in 2013-2016

\begin{tabular}{|l|c|}
\hline \multicolumn{1}{|c|}{ Indicators } & Indicator values \\
\hline $\begin{array}{l}\text { Identified cases of non-submission/ delayed submission of reports on } \\
\text { controlled transactions and incomplete reporting of performed transactions in } \\
\text { submitted reports, cases }\end{array}$ & 206 \\
\hline Penalties applied, mln. UAH & 67,0 \\
\hline Of which budget revenues, mln. UAH & $60,24,2 \%)$ \\
\hline $\begin{array}{l}\text { Taxpayers to whom requests for transfer pricing report submission have been } \\
\text { sent, taxpayers }\end{array}$ & 23 \\
\hline $\begin{array}{l}\text { Number of audits completed in 2017, } \\
\text { of which }\end{array}$ & \\
\hline exporters of agricultural goods & 10 \\
\hline industrial producers $($ export / import) & 8 \\
\hline food producers & 2 \\
\hline transfer of intangible assets & 1 \\
\hline IT services & 1 \\
\hline maritime leasing services & 1 \\
\hline As a result of which income tax was accrued, mln. UAH & 297,8 \\
\hline VAT, mln. UAH & 1,4 \\
\hline Reduced negative value of taxable entity, mln. UAH & 3715,2 \\
\hline Reduced amount of VAT reimbursement, mln. UAH & 2,6 \\
\hline Reduced negative value of VAT, mln. UAH & 0,4 \\
\hline The state budget received revenues from the tax on income, mln. UAH & 65,6 \\
\hline The state budget received revenues from value added tax, mln. UAH & 0,1 \\
\hline
\end{tabular}

Source: calculated by authors on the data of the State Fiscal Service of Ukraine

\section{CONCLUSIONS AND RECOMMENDATIONS}

The current global DE offshorization trend and European integration processes in Ukraine have resulted in much tighter control over the transactions of international companies. Consequently, it has significantly affected the volume and structure of controlled exports and imports brought in and out by the entities engaged in foreign economic activities in Ukraine.

The analysis of changes in the legislation of Ukraine during adaptation to the European standards has made it possible to conclude that since 2013 the government list of low tax jurisdictions has significantly changed and expanded from 36 in 2013 to 85 countries (territories) in 2018. However, only half of the countries in the list are virtually involved in the foreign economic activity of Ukraine.

The deeper research has revealed that immediately after expanding the list of low tax jurisdictions, there has been a significant fall in the volume of controlled exports and imports, 
DOI: 10.14807/ijmp.v11i9.1412

which we regard as a loss of cost-effectiveness of trade operations through low tax jurisdictions due to increased controls and enlarged list of territories, transactions through which are under strict control. In 2018 the share of controlled exports and imports has increased remarkably (from $4.72 \%$ in 2017 up to $11.8 \%$ in 2018 for exports and from $2.02 \%$ in 2017 up to $3.22 \%$ in 2018 for import), which, in our opinion, has happened because of a qualitative change in the list of low tax jurisdictions.

The investigation of the structure of exports and imports by geographical segments has identified top- 10 low-tax jurisdictions by volume of goods. Thus, during 2016-2018 among all low-tax jurisdictions mentioned in the government list, the largest volumes of exports and imports was reported concerning the transactions with contractors from Bulgaria. Other countries were Turkmenistan, Ireland and Hong Kong.

In general, the process of implementing the steps of Plan BEPS in Ukraine is gradual and effective; there is an improvement in legislation in the field of transfer pricing control, international coordination procedures, in the field of avoidance of double taxation and more. On January 1, 2017, Ukraine joined the Enhanced Cooperation Program within the Organization for Economic Cooperation and Development and committed itself to implementing the minimum standard of the Action Plan to combat the erosion of the tax base and the withdrawal of profits from taxation.

Ukraine is obliged to implement four steps out of the fifteen proposed, namely: step 5 "Improvement of measures to combat tax abuse"; step 6 "Prevention of abuse of benefits provided by bilateral agreements"; step 13 "Recommendations on transfer pricing and disclosure documentation by country"; step 14 "Improving the mutual agreement procedure by resolving disputes".

The Ministry of Finance of Ukraine has developed a roadmap for the implementation of the BEPS Action Plan, which will implement the next steps of Plan BEPS, aimed at counteracting the erosion of the tax base. Given Ukraine's clear course towards European integration, it can be concluded that the procedures for strengthening control over exports and imports to low-tax jurisdictions and control over transfer pricing will be improved taking into account the new requirements of the Organization for Economic Cooperation and Development. 


\section{REFERENCES}

ALEKSJEJEVA, A., IGHNATENKO, T. (2014) Transfertne tsinoutvorennia yak mekhanizm podatkovoho kontroliu [Transfer pricing as a tax control mechanism]. Visnyk Kyjivsjkogho nacionaljnogho torghoveljno-ekonomichnogho universytetu, v. 3, p. 85-95. Available: http://nbuv.gov.ua/UJRN/Vknteu_2014_3_8. Access: 10 April 2020.

ANTONIUK, O.; CHYZHEVSKA, L.; SEMENYSHENA, N. (2019) Legal regulation and trends of audit services: what are the differences (evidence of Ukraine). Independent Journal of Management \& Production, v. 10, n. 7, p. 673-686. DOI: http://dx.doi.org/10.14807/ijmp.v10i7.903.

AVI-YONAH, R., CLAUSING, K., DURST, M. (2009) Allocating Business Profits for Tax Purposes: A Proposal to Adopt a Formulary Profit Split. Florida Tax Review, v. 5, p. $497-$ 553. Available: https://repository.law.umich.edu/articles/774/. Access: 22 April 2020.

BEEBEEJAUN, A. (2019) The fight against international transfer pricing abuses: a recommendation for Mauritius. International Journal of Law and Management, v. 61, n. 1, p. 205-231. DOI: https://doi.org/10.1108/IJLMA-05-2018-0083

CLIFFORD, S. (2019) Taxing multinationals beyond borders: Financial and locational responses to CFC rules. Journal of Public Economics, v. 173, p. 44-71. DOI: https://doi.org/10.1016/j.jpubeco.2019.01.010

DERZHAVNA FISKALNA SLUZHBA UKRAINY (2017) Zvit pro vykonannia planu roboty Derzhavnoi fiskalnoi sluzhby Ukrainy za 2017 rik [Report on the implementation of the work plan of the State Fiscal Service of Ukraine for 2017]. Available:

<http://sfs.gov.ua/data/files/223549.PDF>. Access: 23 April 2020.

DERZHAVNA FISKALNA SLUZHBA UKRAINY (2018) Zvit Derzhavnoi fiskalnoi sluzhby Ukrainy za 2018 rik [Report of the State Fiscal Service of Ukraine for 2018]. Available: 〈http://sfs.gov.ua/data/files/240396.pdf〉. Access: 12 April 2020.

DEVEREUX, M.; MAFFINI, G. (Eds). (2007) Proceedings of European Tax Policy Forum Conference «The Impact of Corporation Taxes across Borders». Oxford University Centre for Business Taxation. Available: http://eureka.sbs.ox.ac.uk/3395/1/WP0702.pdf. Access: 24 April 2020.

DISCHINGER, M. T.; RIEDEL, N. (2012) Corporate Taxation and the Location of Patents within Multinational Firms. Journal of International Economics, v. 88, n. 1, p. 176-185. DOI: https://doi.org/10.1016/j.jpubeco.2010.12.002

ECCLESTON, R.; SMITH, H. (2016) The G20, BEPS and the future of international tax governance. In P. Dietsch \& T. Rixen (Eds.). Global tax governance: What is wrong with it and how to fix it (p. 175-198). Colchester: ECPR Press.

FESENKO, V. V. (2018) Zovnishnoekonomichni operatsii pidpryiemstva z poviazanymy storonamy: audyt i analiz [Foreign economic transactions of an enterprise with related parties: audit and analysis]. Dnipro: Dominanta print.

HIRA, A.; MURATA, B.; MONSON, S. (2019). Regulatory Mayhem in Finance: What Panama Papers Reveal. In HIRA, A.; CAILLARD, N.; COHN, T. H. (Eds.). The Failure of Financial Regulation (p. 191-232). Burnaby: Simon Fraser University. 
INDEPENDENT JOURNAL OF MANAGEMENT \& PRODUCTION (IJM\&P)

http://www.ijmp.jor.br

v. 11, n. 9, Special Edition (Baltic States), November 2020

ISSN: 2236-269X

DOI: 10.14807/ijmp.v11i9.1412

HUDA, M.; NUGRAHENI, N.; KAMARUDIN, K. (2017) The Problem of Transfer Pricing in Indonesia Taxation System. International Journal of Economics and Financial Issues, v. 7, n. 4, p. 139-143. Available:

<https://www.econjournals.com/index.php/ijefi/article/view/4793/pdf>. Access: 12 April 2020 .

INTERNATIONAL CONVENTION ON THE SIMPLIFICATION AND

HARMONIZATION OF CUSTOMS PROCEDURES. Available:

<http://zakon4.rada.gov.ua/laws/show/995_643/>. Access: 18 April 2020.

IVASHOVA, L. M.; IVASHOV, M. F. (2014) Dosvid derzhavnoho finansovoho kontroliu v krainakh YeS ta napriamy yoho implementatsii do Ukrainy [Experience of state financial control in the EU countries and directions of its implementation in Ukraine]. Visnyk

Akademii mytnoi sluzhby Ukrainy. Seriia: Derzhavne upravlinnia, v. 2, n. 11, p. 12-23. Available: <http://nbuv.gov.ua/UJRN/vamcudu_2014_2_4. Access: 12 April 2020>.

KHALATUR, S.; RADZEVICIUS, G.; VELYCHKO, L.; FESENKO, V.; KRIUCHKO, L. (2019) Global deoffshorization and its impact on the national and regional economies of eastern european countries. Problems and Perspectives in Management, v. 17, n. 3, p. 293 305. doi:10.21511/ppm.

LARSEN, M. M. (2015) Failing to estimate the costs of off shoring: A study on process performance. International Business Review, v. 25, n. 1, p. 307-318. DOI:

https://doi.org/10.1016/j.ibusrev.2015.05.008.

LOHSE, T.; RIEDEL, N. (2013) Do Transfer Pricing Laws Limit International Income Shifting? Evidence from European Multinationals. CESifo Working Paper Series No. 4404. Available: <https://ssrn.com/abstract=2334651>. Access: 19 April 2020.

MARQUES, M.; PINHO, C. (2015). Is transfer pricing strictness deterring profit shifting within multinationals? Empirical evidence from Europe. Accounting and Business

Research, v. 46, n. 7, p. 703-730. Available: <https://ssrn.com/abstract=2709035>. Access:

21 April 2020.

MARQUES, M.; PINHO, C.; MONTENEGRO, T. (2019) The effect of international income shifting on the link between real investment and corporate taxation. Journal of International Accounting, Auditing and Taxation, v. 36. DOI:

https://doi.org/10.1016/j.intaccaudtax.2019.100268.

MELNYCHENKO, R.; PUGACHEVSKA, K.; KASIANOK, K. (2017) Tax control of transfer pricing. Investment Management and Financial Innovations, v. 14, n. 4, 40-49. DOI: http://dx.doi.org/10.21511/imfi.14(4).2017.05.

CUSTOMS CODE OF UKRAINE (2012). Available:

<http://zakon3.rada.gov.ua/laws/show/4495-17>. Access: 22 April 2020

OECD TRANSFER PRICING GUIDELINES FOR MULTINATIONAL ENTERPRISES

AND TAX ADMINISTRATIONS. (2017). DOI: https://dx.doi.org/10.1787/tpg-2017-en

Available:

<http://www.svcmscentral.com/SVsitefiles/nlc/contenido/doc/073214_OECD\%20TP\%20Gui delines\%20June\%202010.pdf>. Access: 05 May 2020.

OFITSIINYI SAIT DERZHAVNOI SLUZHBY STATYSTYKY UKRAINY.Official site of the State Committee of Statistics of Ukraine. Available: <http//www.ukrstat.gov.ua>.

Access: 12 May 2020. 
PETRYK, O. A.; KASYCH, A. O.; GHRYNENKO, Ju. I. (2016) Transfertne tsinoutvorennia na pidpryiemstvi: problemy ta mozhlyvosti vykorystannia [Transfer pricing in the enterprise: problems and opportunities for use]. Investyciji: praktyka ta dosvid, n. 24, p. 19-23. Available: <http://nbuv.gov.ua/UJRN/ipd_2016_24_6>. Access: 26 April 2020

PETRYK, O. A.; MARYNICH, I. O. (2015) Rol nezalezhnoho audytu v provedenni postmytnoho kontroliu [The role of independent audit in post customs control]. Technology audit and production reserves, v. 1/6, n. 21, p. 57-60. Available:

<http://journals.uran.ua/tarp/article/view/38439>. Access: 19 April 2020.

PRETTL, A. (February 2018). Profit Shifting \& Controlled Foreign Corporation Rules the Thin Bridge between Corporate Tax Systems. DOI:

http://dx.doi.org/10.2139/ssrn.3102553

RAKHUNKOVA PALATA UKRAINY. (2016) Zvit pro rezultaty audytu efektyvnosti vykonannia povnovazhen terytorialnymy orhanamy Derzhavnoi fiskalnoi sluzhby za dotrymanniam subiektamy hospodariuvannia, yaki zdiisniuiut zovnishnoekonomichnu diialnist, zakonodavstva Ukrainy z pytan derzhavnoi mytnoi spravy za 2016 rik [Report on the results of the audit of the effectiveness of the execution of powers by the territorial bodies of the State Fiscal Service for compliance by business entities that carry out foreign economic activity with the legislation of Ukraine on state customs for 2016]. Available: <http://www.ac-rada.gov.ua/doccatalog/document/16749201/Zvit_5-7.pdf?subportal=main>. Access: 12 May 2020.

RUF, M.; WEICHENRIEDER, A. (2015) The Taxation of Passive Foreign Investment: Lessons from German Experience. Canadian Journal of Economics. DOI: https://doi.org/10.1111/j.1540-5982.2012.01737.x

SHALIMOVA, N. (2017) The Public Function of a Statutory Audit. Innovation Economics and Management, v. IV, n. 2, p. 63-72. Available:

<http://dspace.kntu.kr.ua/jspui/handle/123456789/7065>. Access: 22 April 2020.

SINENKO, O.; MAYBUROV, I. (2017) Comparative Analysis of the Effectiveness of Special Economic Zones and Their Influence on the Development of Territories.

International Journal of Economics and Financial Issues, v. 7, n. 1, p. 15-122. Available: <https://www.econjournals.com/index.php/ijefi/article/view/3374>. Access: 01 May 2020.

VAKULCHYK, O.; FESENKO, V.; KNYSHEK, O. (2017) Internal control and audit of enterprises' compliance with customs requirements while conducting foreign economic activity. Baltic Journal of Economic Studies, v. 3, n. 4, p. 18-23. DOI:

http://dx.doi.org/10.30525/2256-0742/2017-3-4-18-23.

VAKULJCHYK, O. M.; RJABYCH, O. V. (2015) The transfer pricing control mechanism and reporting system implementation challenges: Ukrainian experience. Customs, v. 2, p. 1016. Available: 〈http://212.1.86.13/jspui/handle/123456789/2134>. Access: 12 April 2020.

WEST, C. (2017) Status Quo of International Tax Reform in South Africa: Implementation of BEPS and CRS and the Influence on Domestic Law Amendment. SSRNElectronic Journal. DOI http://dx.doi.org/10.2139/ssrn.3009193 Available: <https://ssrn.com/abstract=3009193>. Access: 24 April 2020.

ZADOROZHNYJ, Z.; KAFKA, S.; ORLOVA, V. (2018) Bukhhalterskyi ta upravlinskyi oblik spilnoi diialnosti pidpryiemstv z vykorystanniam osnovnykh zasobiv [Accounting and management accounting of joint ventures using fixed assets]. Visnyk Ternopiljsjkogho nacionaljnogho ekonomichnogho universytetu, v. 2, p. 84-93. Available: <http://nbuv.gov.ua/UJRN/Vtneu_2018_2_10>. Access: 26 April 2020. 